\title{
Syngas Analysis of Lowrank Coal Gasification Downdraft Products with Variations in Air Flow Rate
}

\author{
Aida Syarif ${ }^{1, *}$ Neli Masnila ${ }^{2}$, Indrayani Indrayani ${ }^{3}$, M. Yerizam ${ }^{4}$, \\ Apriansyah Zulatama ${ }^{5}$, Sarmidi Sarmidi ${ }^{6}$, MirzaAdiwarma $^{7}$ \\ ${ }^{1)}$ Renewable Energy Engineering Department, Politeknik Negeri Sriwijaya, Palembang, Indonesia \\ ${ }^{2)}$ Public Sector Accounting Department, Politeknik Negeri Sriwijaya, Palembang, Indonesia \\ ${ }^{3)}$ Civil Engineering Department, Politeknik Negeri Sriwijaya, Palembang, Indonesia \\ ${ }^{4)}$ Chemical Engineering Department, Politeknik Negeri Sriwijaya, Palembang, Indonesia \\ ${ }^{5,6,7)}$ Processing of Mineral and Coal Mining Products Study Program, Community Academic Bukit Asam \\ *Corresponding Author, E-mail :aida_s@polsri.ac.id
}

\begin{abstract}
Coalgasificationistheprocessofconvertingsolidintoagasmixturethathasfuelvalue.Coalgasificationwillproducegas in the form of synthetic gas (syngas) with the main components consisting of carbon monoxide $(\mathrm{CO})$, hydrogen $\left(\mathrm{H}_{2}\right)$, and $\left(\mathrm{CH}_{4}\right)$ gas. By converting coal using gasification as a clean energy producer, a blower as a regulator of air flow, cyclones as a tar separator and a gas cooler. The results of this study are the rate of fuel use, the rate of burning ash, the specific gestation rate, the specific gas production rate, the syngas flow rate, the flash point calorific value, and the efficiency of the classification process. The decrease in the combustion air flow rate will tend to make the combustion temperature and the calorific value become smaller so that the efficiency will also decrease. The best efficiency occurs at the largest airflow rate of $3.15 \mathrm{~m} / \mathrm{s}$ with an efficiency of $84.62 \%$. The increase in the mass of thehuskthatisfilteredwillcauseanincreaseinthecompositionofCH4andH2, aswellasadecreaseinCO2andCO.Byfilteringthe massof rice husks, the LHV value will increase.
\end{abstract}

Keywords: Low rank coal, downdraft gasification, air flow, syngas, LHV

\section{INTRODUCTION}

Indonesia has abundant coal reserve potential. According to data from the Ministry of Energy and Mineral Resources in 2011, Indonesia's total coal is estimated at 119.4 billion tons, of which $48 \%$ is located in South Sumatra with $70 \%$ of coal deposits are young or low-quality coal. According to data from the Ministry of Energy and Mineral Resources in 2019, coal production in 2018 increased to 528 million tons compared to 2017 production of 461 million tons. [1][2]

Installed capacity for power plants in 2018 came mostly from fossil energy plants, especially coal (50\%), followed by natural gas (29\%), fuel (7\%) and renewable energy (14\%). This is due to the amount of coal production that is still abundant and the price of coal is still cheap [3][4].
If it is assumed that the growth rate of coal production reaches $12.4 \%$ per year, then Indonesian coal can be utilized up to 2166 [5]. Behind the reasons for choosing coal as a source of power generation energy, there are still some shortcomings of the use of coal directly. Coal also contains many pollutants that are harmful to the environment. Coal releases gases $\left(\mathrm{CO}_{2}\right.$, $\mathrm{N}_{2} \mathrm{O}$, NOx, SOx and $\mathrm{Hg}$ ) that cause global warming. Therefore, the use of clean and efficient coal still remains a challenge that needs to be pursued extensively in order to extend the life of its availability. In addition to minimizing global environmental burdens, one way to increase the utilization of clean coal is by the coal gasification process [6].

Coal gasification is a process to convert solid coal into a mixture of gases that have a fuel value [7]. 


\subsection{Downdraft Gasification}

The development of gasification technology makes the process of gasifier research and development continues. Development is done with various considerations include reducing the content of tar and sulphur in syngas results. A downdraft gasifier is a reactor with the direction of air flow and raw materials both heading down. Syngas flows down and gasifier [8].Downdraft type gasifier was due to 4 things, namely:

1. Cheaper manufacturing costs,

2. The resulting gas is hotter than the updraft system

3. It is easier to proceed to the combustion process

4. Lower tar than updraft.

\subsection{Effect Air Flow Ratio on Gasification}

Gasifier Coal as a syngas producer can be reviewed from several parameters, one of which is the rate of combustion air. Because of the good or bad of a combustion process such as pyrolysis and gasification in the gasifier is also affected by the air that must be supplied, eventually it will affect the syngas produced. So that the review of the rate of air flow needed as one of the elements in the gasifiation process while helping the flow rate of the combustion gas requires the right ratio. So the problem in this study is how the effect of air flow rate in producing maximum syngas and its effect on operating conditions [9][10].

\subsection{Calculation of Gasification}

In reviewing the type of coal against syngas results, there are several parameters that need to be considered to determine syngas results such as the following [11]:

\subsubsection{Fuel Consumption Rate (FCR)}

The amount of raw materials used in operation in the reactor is divided by the operating time. It can be calculated using the formula:

$F C R=\frac{\text { MASS OF SOLID FULEL }(l B)}{\text { TIME OF RATE }(S)}$

\subsubsection{Air Fuel Ratio Stoichiometry}

To calculate AFR Stoichiometry one operation with the ultimate composition value of coal can use the following equation

$$
A F R S=\frac{1}{0 . .23}\left(\frac{8}{3} C+8 H 2+S-02\right)(2)
$$

\subsubsection{Gas Heating Value}

Energy content refers to the heat heating value and it affects the gasifier's energy output. In this study LHV was used in the analysis and calculated from: [12]

$$
\begin{gathered}
\text { LHVgas }=\quad 10,768 \\
{[\mathrm{CO}]+35,866\left[\mathrm{CH}_{4}\right]+83.800[\mathrm{CnHm}]}
\end{gathered}
$$

In this case to get LHV is based on normal conditions for each gas producer. Percent of the volumetrics of hydrogen, carbon monoxide, methane and any other hydrocarbons are known from the results of gas chromatography.

\section{RESEARCH METHODS}

\subsection{Material}

In the research analysis of low-rating coal downdraft gasification performance review of variations in air flow rates and variations in filters to processes and products of gasification Variable fixed in this study is coal subbituminus $5108 \mathrm{Kcal} / \mathrm{kg}$ s with coal size $7-8 \mathrm{~cm}$.

\subsection{Methods}

This research was conducted at the Sriwijaya Polytechnic Energy Engineering Laboratory from July 6 to August 10, 2020, the problem that will be studied in this study is the effect of air flow valve openings of $100 \%, 75 \%$, and $50 \%$ as well as variations in filter mass of $200 \mathrm{gr}, 400 \mathrm{gr}$, and $600 \mathrm{gr}$ on syngas composition, LHV, and Gasification Efficiency. In this study, a preliminary analysis was conducted to Analysis on Proximate and Ultimate. Analysis using ASTM D 317303 For moisture analysis, ASTM 3175-07 for Volatile matter, ASTM3175-07 for Volatile matter, ASTM 3175-02forash, forfixcarbon. Ultimate analysis using PT. Geoservices Palembang with the method used ASTM-D4239 method A-2017 for total sulfur, ASTMD5373-2016 for Ultimate Instrument, ASTM-D31762015 for oxygen by difference. To find out the value of syngas composition using GC-MS (ASTM) tools. D2163 from Pertamina RU III Plaju-Palembang [13]

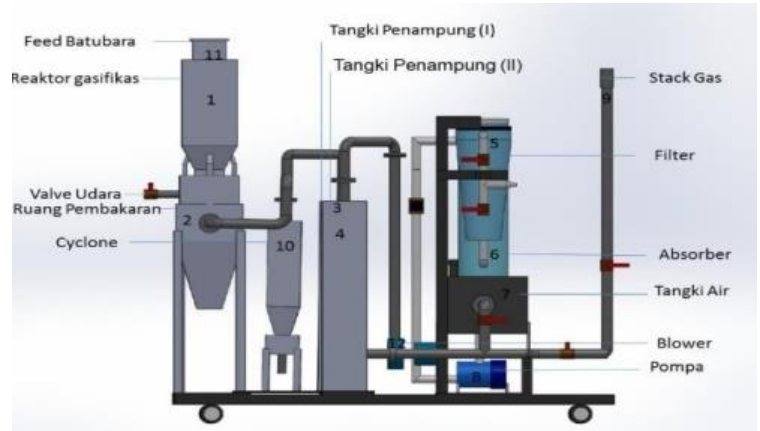

Figure 1 Design of Reactor Gasification 


\section{RESULTS AND DISCUSSIONS}

From the actual data obtained and the results of calculations obtained, it can be analyzed and studied related to the influence of air flow lanes on several parameters in the gasification process this time. In addition to these data, also obtained the composition of coal as a fuel by conducting the ultimate analysis in the Palembang Geoservice laboratory and also analyze the composition of syngas in the form of $\mathrm{H} 2, \mathrm{O} 2, \mathrm{~N} 2, \mathrm{CO}$, $\mathrm{CO} 2$ and $\mathrm{CH} 4$ conducted, using GC-MS (ASTM-D2163) analyzer from PertaminaRU-III Plaju Palembang. Gas samples from gasification are taken at the time when the syngas burned produces a constant fire [14].

\subsection{Effect of air flow rate on fuel consumption}

The rate of combustion air flow is very influential with the rate of coal use or in other words the rate of air flow affects the length or absence of a gasification process taking place in the reactor, this can happen because of the process gasification process takes place inside the reactor, this can occur because the combustion process is influenced by the fire triangle and one of them is oxygen, and in this case oxygen in the supply of air supplied with a blower, because when oxygen is limited it can break the chain of fire so that combustion becomes slow [15].

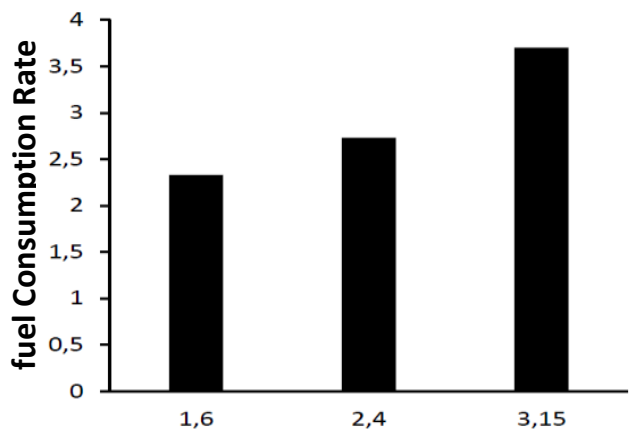

Air Flow rate $(\mathrm{m} / \mathrm{s})$

Figure 2 Graph of the relationship between the rate of air flow and the rate of fuel consumption

Figure 2 shows that the greater the rate of combustion air flow, the faster the rate of coal use during the gasification process, as previous research conducted by Arizandy (2014) is because the coal combustion process is accelerating as the volume of air flow is supplied.

\subsection{Effect of Air Flow Rate on SGR and SPGR}

In this study, it was analyzed how the process of gasification takes place, and how the speed of the gasification process is in units of time, and in this case called SGR and SPGR or Specific Gasification Rate is the amount of fuel that is qualified per unit. time through a throat with a certain cross-sectional area [16][17]. SGR is often also referred to by the name of heart load with the terminology of the amount of fuel that is qualified. Of course, in this case the value of SGR is related to the large rate of air flow of the combustion supply, because the rate of air flow affects the amount of fuel consumption used each unit of time.

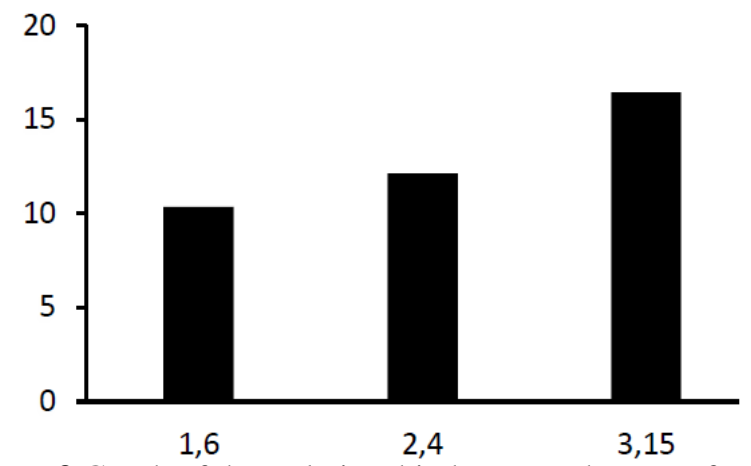

Figure 3 Graph of the Relationship between the rate of Air Flow and SGR and SPGR

\subsection{Effect of Air Flow Rate on Heat Heating Value}

Heat value is the amount of heat that a certain amount of fuel can release in a combustion reaction. The effect of increasing the flow rate of combustion air causes the oxygen supply in the combustion reaction to increase which affects lhv syngas results. From figure 4 above it can be seen that from the air range of $3.1 \mathrm{~m} / \mathrm{s}$ to $1.5 \mathrm{~m} / \mathrm{s}$ heating value or the highest heat value is located at the highest supply air flow speed is also at 3.1 $\mathrm{m} / \mathrm{s}[18]$.

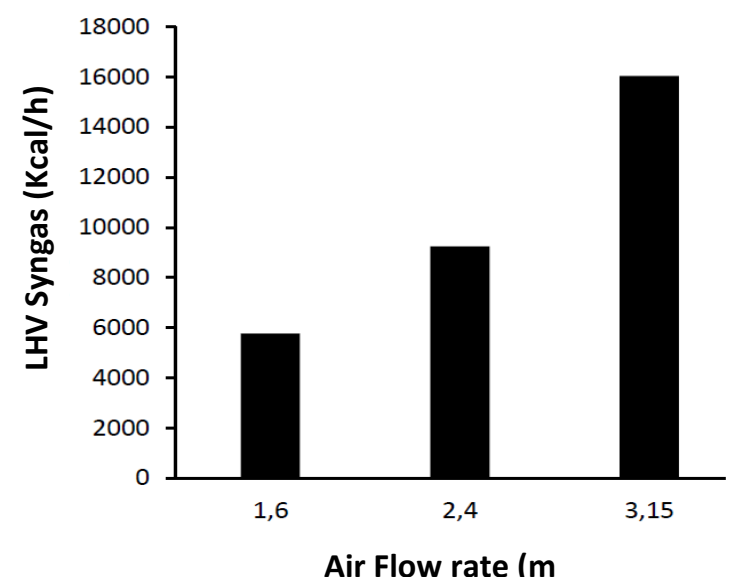

Figure 4 Graph of the relationship between Rate of Flow Air and LHV

High syngas heat value is expected from the gasification process, because high heat value will be very influential in improving gasification efficiency. In addition, with a 
high syngas heat value, the syngas will be more flammable and will be easier to use as fuel. But related to the relationship of air flow rate and heat value is not a straight line relationship which means there is a time when the air supply is too much or excessive then the heat value will decrease,As research has been done if the combustion reaction process has entered the stage of perfect combustion and does not create gas capable of combustion or syngas [19][20].

\section{CONCLUSION}

The rate of air flow used is $3.15 \mathrm{~m} / \mathrm{s}, 2.4 \mathrm{~m} / \mathrm{s}, 1.6 \mathrm{~m} / \mathrm{s}$, and the rate of combustion air flow is directly proportional to the rate of coal, sgr and sgpr usage, syngas flow rate, heating value of syngas, efficiency of gasification, but inversely proportional to the rate of ash leftover combustion. Air flow rate effects the value of SGR and SPGR syngas where the result obtained for the flow rate of $13.51 / \mathrm{m} 18 \mathrm{~g} \mathrm{~m} / \mathrm{s}$. The rate of air flow effects the value of LHV syngas where with the increasing flow rate value, the value of LHV syngas also increases the results obtained for the flow rate of $13.5 \mathrm{~m} 3$ / minute obtained LHV $1800 \mathrm{Kcal} /$ hour.

\section{REFERENCES}

[1] ESDM. Handbook of Energy and Economic Statistics of Indonesia. Jakarta: Lembaga Ilmu Pengetahuan Indonesia. 2019.

[2] R. Ploetz, R. Rusdianasari, E. Eviliana, Renewable Energy: Advantages and Disadvantages, Proceeding Forum in Research, Science, and Technology (FIRST), 2016.

[3] ASTMD 3173-03, Standard Testing Method for Moisture in the Analysis Sample of Coal and Coke, Annual Books of ASTM Standard, USA, 2008.

[4] Julismi, Rusdianasari, A. Hasan, Syngas Underground Coal Gasification (UCG) Testing of In-Situ Type Lignite Coal and Fracture Type Coal, International Journal of Research in Vocational Studies (IJRVOCAS),Vol. 1, No. 2, 2021, pp. 6778.

[5] Apriansyah Z. A. Syarif, M. Yerizam, Effect of Oxygen Flow Rate on Combustion time and Temperatur of underground Coal Gasification, IJRVOCAS Vol 1 No 2, 2021

[6] Rusdianasari, S. Arita, E.Ibrahim, and Ngudiantoro, Reduction of Metal Contents in Coal Stockpile Wastewater using Electrocoagulation, Applied Mechanics and Materials Vol. 391.2013.pp 29-33
[7]Chuvieco,E.,Riaño,D.,VanWagtendok,J.,danMorsdo f, F. Fuel Loads and Fuel TypeMapping.2003. 119-142.

[8]Dafiqurrohman,H.,Setyawan,M.I.B.,danYoshikawa, K.TarReductionUsingAnIndirectWaterCondensera ndRiceStraw.ScienceDirectNo.100696,Mechanical Engineering,UniversitasIndonesia, Depok, 2020.

[9]Lubwama, Michael. Technical Assesment Of The Functional And Operational Performance Of A Fixed Bed Biomass Gasifier Using Agricultural Residue. Master Of Science Thesis Energy Technology, KTH School Of Industrial Engineering And Management Division Of Heat And Power Technology, Stockholm. 2010.

[10] Rusdianasari, A. Taqwa, and Y. Bow, Treatment of Coal Stockpile Wastewater by Electrocoagulation Using Aluminum Electrodes, Advanced Materials Research.Vol. 896. 2014. pp 145-148.

[11] Kumar, P.S., K. Ramakrishnan, S.D. Kirupha, dan S.Sivanesan. Thermodynamic and Kinetic Studies of Cadmium Adsorption from Aqueous Solution onto Rice Husk, Brazilian Journal of Chemical Engineering, Vol.27, No.02,2010. pp.347-355, hlm:1-9

[12] D. Doucet, G. Perkins, A. Ulbrich, and ED Toit, Production of Power using Underground Coal Gasification, Energy Sources, part A: Recovery, Utilization, and Environmental Effect, vol. 38(24), 2016, pp. 3653-3660.

[13] M. Gur and E.D. Canbaz, Analysis of Syngas Production and Reaction Zones in Hydrogen Oriented Undeground Coal Gasification, Fuel, Vol. 269, June 2020.

[14] S.B. Javed, A.A. Uppa, A.I. Bhatti, and R. Samar, Prediction and Parametric Analysis of Cavity Growth for the Underground Coal Gasification Project Thar,Energy, Vol. 172, pp. April 2019. 1277-1290.

[15] Rusdianasari, S. Arita, E. Ibrahim, and Ngudiantoro, Evaluation on Environmental Effect of Coal Stockpile in MuaraTelang, Banyuasin, Indonesia, Journal of Physic Conference Series, 423, 2013.

[16] P. Pei, S. Korom, K. Ling, and J. Nasah, Cost Comparison og Syngas production from Natural Gas Convertion and Underground Coal Gasification, Mitigation and Adaption Strategies for Global Change, Vol. 21, 2016. pp. 629-643. 
[17] G. Perkin, ED Toit, G Cochrane, and G. Bollaert, Overview of Underground Coal Gasification Operations at Chinchlilla, Australia, Energy Sources, part A: Recovery, Utilization, and Environmental Effect, vol. 38(24), 2016. pp. 36393646.

[18] Y. Bicer and I. Dincer, Energy and Exergy Analyses of an Integrated Underground Coal Gasification with SOFC Fuel Cell System for Multigeneration including Hydrogen Production, International Journal of Hydrogen Energy, Vol. 40(39), October 2015. pp. 13323-13337.
[19] G. X. Wang, Z.T. Wang, B.Feng, V. Rudolph, and J.L. Jiao, Semi-industrial Tests on Enhanced Underground Coal Gasification at Zhong-LiangShan Coal Mine, Asia-Pasific Journal of Chemical Engineering, Vol. 4(5), October 2009, pp. 771779 .

[20] Rusdianasari, S. Arita, E. Ibrahim, and Ngudiantoro, Characteristic of Coal Stocpile in Lowland and the effect to Environment, Springer Series in Materials Science, Volume 204 in Recent Trends in Physics of material Science and Technology, 